\title{
Herbal mixtures in traditional medicine in Northern Peru
}

\author{
Rainer W Bussmann*, Ashley Glenn, Karen Meyer, Alyse Kuhlman and Andrew Townesmith
}

\begin{abstract}
The investigation of plant mixtures used in traditional medicine in Northern Peru yielded a total of 974 herbal preparations used to treat 164 different afflictions. Psychosomatic disorders were, with almost 30\% of all recipes applied, the most important afflictions treated. In most cases, healers used only one or two mixtures to treat an illness. However, up to 49 different preparations were used to treat the same disease. This indicates a high degree of experimentation. Altogether 330 plant species, representing almost $65 \%$ of the medicinal flora used in the region were applied in mixtures. The overwhelming number of plant mixtures contained 2-7 different plant species, although in the most extreme case 27 distinct species were included. The cluster analysis confirmed that mixtures used for applications like inflammations, infections and blood purification, as well as cough, cold, bronchitis or other respiratory disorders, or urinary infection and kidney problems had similar floristic compositions. Mixtures used for nervous system disorders, anxiety and heart problems often had a similar composition
\end{abstract}

\section{Introduction}

Traditional Medicine, defined by the WHO as " medical knowledge systems that developed over generations within various societies before the era of modern medicine, including the health practices, approaches, knowledge and beliefs incorporating plant, animal and mineralbased medicines, spiritual therapies, manual techniques and exercises, applied singularly or in combination to treat, diagnose and prevent illnesses or maintain wellbeing." [1] is used globally and has rapidly growing economic importance. In developing countries, Traditional Medicine is often the only accessible and affordable treatment available. In Latin America, the WHO Regional Office for the Americas (AMRO/PAHO) reports that $71 \%$ of the population in Chile and $40 \%$ of the population in Colombia have used Traditional Medicine. In many Asian countries Traditional Medicine is widely used, even though Western medicine is often readily available. In Japan, $60-70 \%$ of allopathic doctors prescribe traditional medicines for their patients. In the US the number of visits to providers of Complementary Alternative Medicine (CAM, codified herbal medicine) now exceeds by far the number of visits to all primary care physicians [1-3].

\footnotetext{
*Correspondence: rainer.bussmann@mobot.org

1 William L Brown Center, Missouri Botanical Garden, PO Box 299, St Louis, MO 63166-0299, USA
}

Complementary Alternative Medicine is also becoming more and more popular in many developed countries. Forty-two percent of the population in the US have used Complementary Alternative Medicine at least once [4], and a national survey reported the use of at least one of 16 alternative therapies increased from $34 \%$ in 1990 to $42 \%$ in 1997 [5].

The expense for the use of Traditional and Complementary Alternative Medicine is exponentially growing in many parts of the world. The 1997 out-of-pocket Complementary Alternative Medicine expenditure was estimated at US\$ 2.7 billion in the USA. The world market for herbal medicines based on traditional knowledge is now estimated at US $\$ 60$ billion [6].

Northern Peru is believed to be the center of the Central Andean Health Axis [7], and traditional medicinal practices in this region are still an important component of everyday life [8-16]. Traditional Medicine is also gaining more and more respect by national governments and health providers. Peru's National Program in Complementary Medicine and the Pan American Health Organization recently compared Complementary Medicine to allopathic medicine in clinics and hospitals operating within the Peruvian Social Security System [17].

According to WHO [3], the sustainable cultivation and harvesting of medicinal species is one of the most important challenges for the next few years. 
Many traditional healers rely on herbal preparations, often consisting of complex ingredients and with very specific preparations, to treat their patients' illnesses, rather than just employing single plant extracts. However, studies documenting these preparations and analyzing the composition of the mixtures are almost non-existent. Most ethnobotanical studies to date document the "use" of single species, without asking the important question if the plants in question are really employed alone, or if they are in fact part of a more complex preparation. Cano \& Volpato [18] and Carmona et al. [19] were amongst the first authors to respond to this challenge, and reported on plant mixtures employed in Cuba and the Middle East, and Vandebroek et al. [20] demonstrated the great complexity of plant preparations in the Dominican Republic. No information however was available for the very species rich Andean pharmacopoeia.

The present publication attempts to give a detailed overview on the herbal mixtures employed by traditional practitioners in Northern Peru and the specific applications they are used for, in order to provide a baseline for more in-depth studies on efficacy and safety of these preparations, as well as the possible applications in the public health system.

\section{Materials and methods Plant Collections}

Plants in the research area in Northern Peru (Fig. 1) were collected in the field, in markets, and at the homes of traditional healers (curanderos) visited in August-September 2001, July-August 2002, July-August 2003, June-August 2004, July-August 2005, July-August 2006, June-August 2007, June-August 2008, March-April 2009 and JuneAugust 2009. The specimens are registered under the collection series "RBU/PL," "ISA," "GER," "JULS," "EHCHL," "VFCHL," "TRUBH," "ACR," "KMM," "ACT," and "TRUVANERICA," depending on the year of fieldwork and collection location. Surveys were conducted in Spanish by fluent speakers. Semi-structured interviews were conducted with curanderos. All were asked to participate, but due to expected resistance information could not collected from everyone.

Vouchers of all specimens were deposited at the Herbario Truxillensis (HUT, Universidad Nacional de Trujillo), and Herbario Antenor Orrego (HAO, Universidad Privada Antenor Orrego Trujillo). In order to recognize Peru's rights under the Convention on Biological Diversity, most notably with regard to the conservation of genetic resources in the framework of a study treating medicinal plants, the identification of the plant material was conducted entirely in Peru. No plant material was exported in any form whatsoever.

\section{Nomenclature}

The nomenclature of plant families, genera, and species follows the Catalogue of the Flowering Plants and Gymnosperms of Peru [21] and the Catalogue of Vascular Plants of Ecuador [22]. The nomenclature was compared to the TROPICOS database. Species were identified using the available volumes of the Flora of Peru [23], as well as [24-26], and the available volumes of the Flora of Ecuador [27], and reference material in the herbaria HUT, HAO, QCA, LOJA and QCNE.

\section{Cluster analysis of plant records}

The goal of cluster analysis is to group objects together that are similar. Data in the literature and market collections were organized in an Excel spreadsheet that contained species as rows and sources as columns. Individual cells contained qualitative presence/absence data, represented by numerical values "1" or "0." The Excel spreadsheet was imported into NCSS (version 2007) and a (dis)similarity matrix was produced using the Simple Matching Coefficient that measures the degree of similarity/dissimilarity between all pairs of mixtures. Next, a dendrogram (tree) was generated. Since a cluster analysis will always yield clusters, it is necessary to demonstrate how well the analysis represents the original (dis)similarity matrix. To this end, the tree matrix is transformed into a matrix of ultrametric distances and the latter matrix is statistically compared with the original (dis)similarity matrix. The resulting correlation coefficient " $r$ " between both matrices (normalized Mantel statistic Z) can be used as a measure of goodness of fit for cluster analysis. This analysis provided an in-depth comparison of the species composition of all mixtures.

\section{Results and Discussion}

The investigation of plant mixtures used in traditional medicine in Northern Peru yielded a total of 974 herbal preparations used to treat 164 different afflictions (Table 1). The classification of diseases followed the curandero's terminology. To allow a better overview the different disease concepts were grouped in more inclusive disease categories, according to their similarity. Psychosomatic disorders were the most outstanding afflictions treated with traditional herbal mixtures, with almost $30 \%$ of all recipes applied, followed by respiratory illnesses, female issues, kidney problems and heart problems (Table 2). Susto (fright), problems of the nervous system, general systemic inflammation and bronchitis together accounted for almost $25 \%$ of all remedies used. In many cases, healers used only one or two common mixtures to treat an illness (Table 3). This degree of consensus between different healers shows great sophistication in the diagnosis and treatment of specific disorders. On the contrary, when it came to the treatment of unspecific disease categories like "inflammation" or "bronchitis", every 


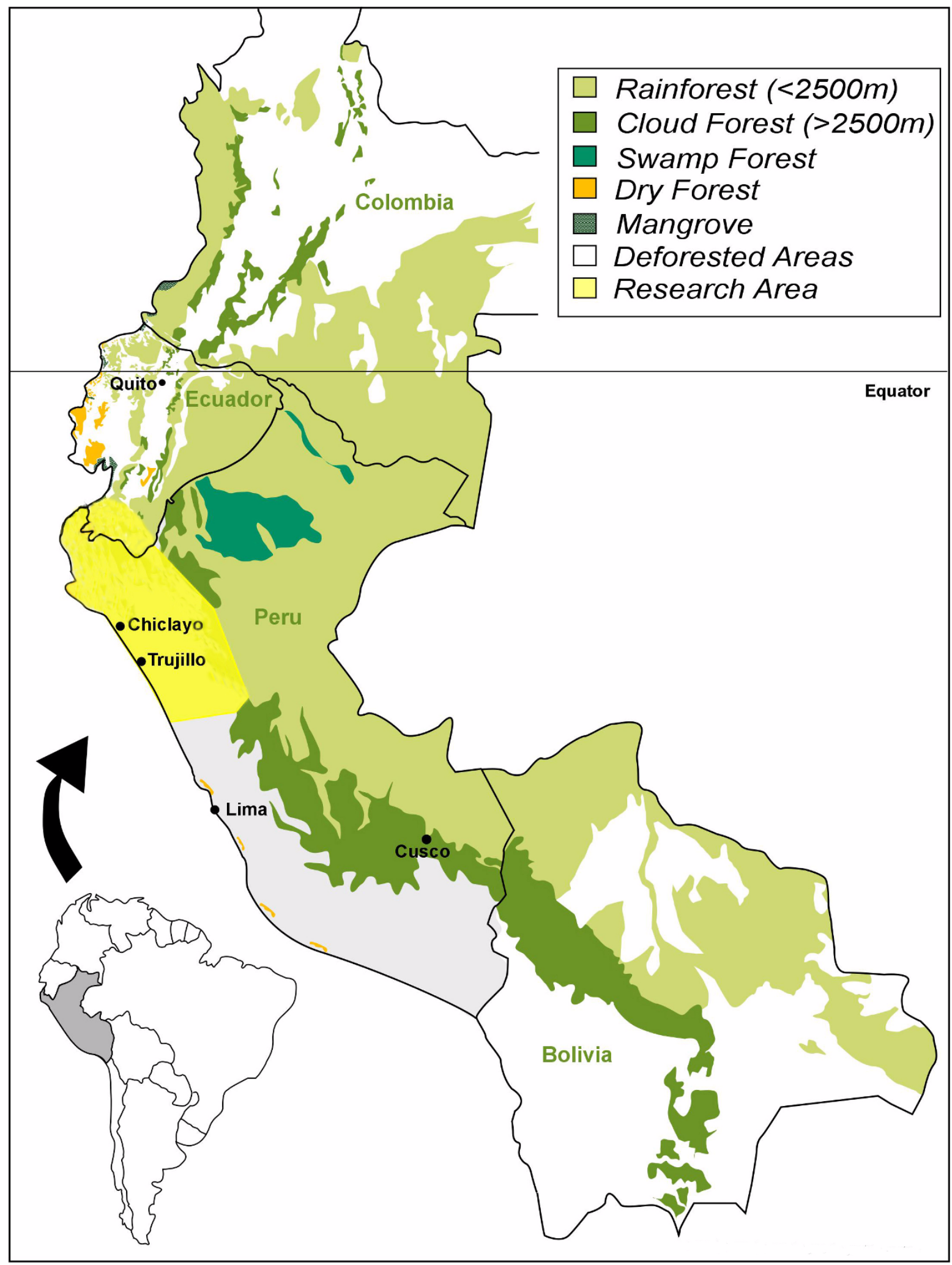


Table 1: Mixtures used in individual disease categories (letter in parenthesis refers to combined category in table 2)

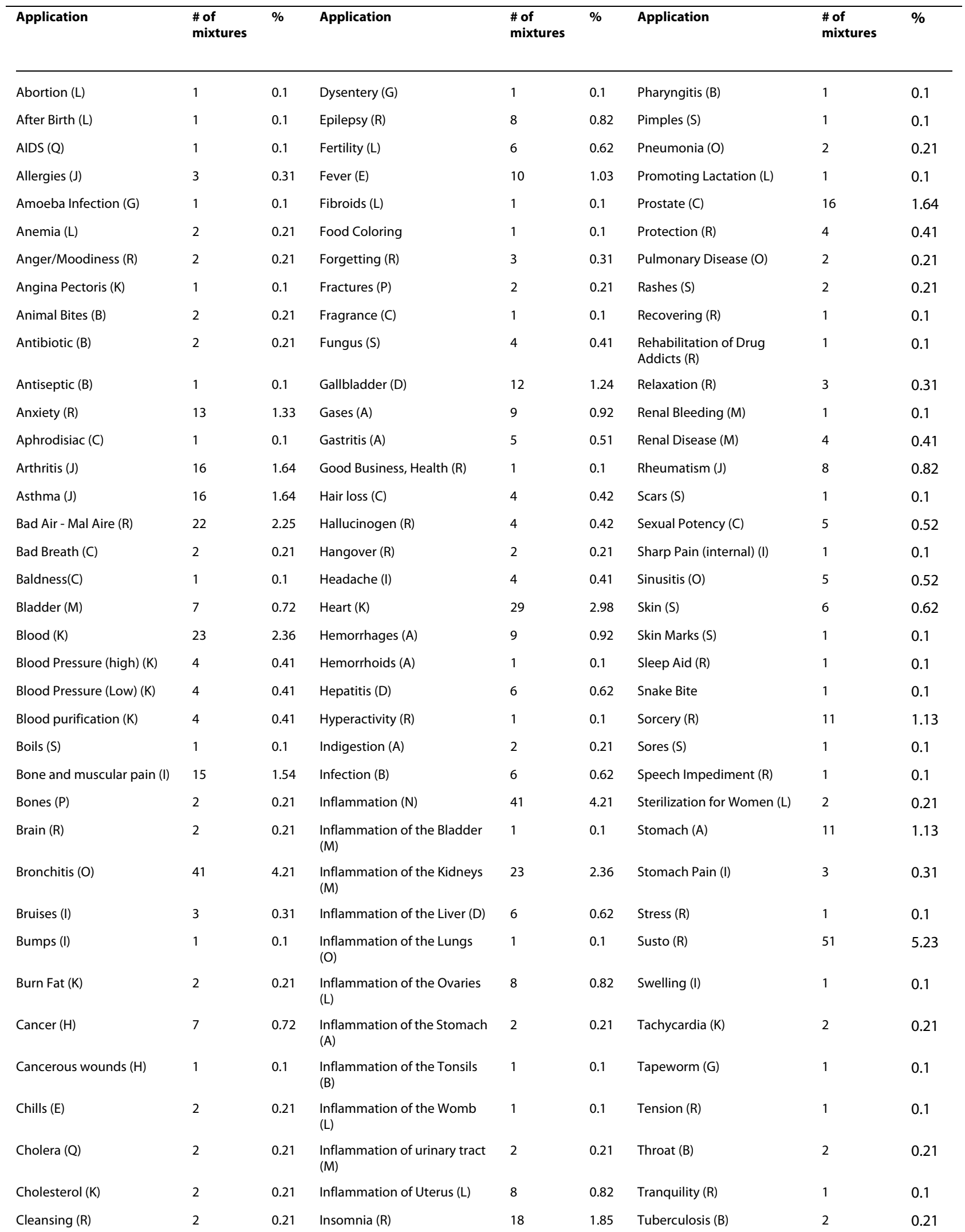


Table 1: Mixtures used in individual disease categories (letter in parenthesis refers to combined category in table 2)

\begin{tabular}{|c|c|c|c|c|c|c|c|c|}
\hline Cold (high mucus) (O) & 1 & 0.1 & Internal Bleeding (A) & 1 & 0.1 & Tumors $(\mathrm{H})$ & 4 & 0.41 \\
\hline Cold Sores (Q) & 1 & 0.1 & Intestine (A) & 3 & 0.31 & Twisted Bones (R) & 1 & 0.1 \\
\hline Colds (O) & 25 & 2.57 & Judgment (R) & 1 & 0.1 & Typhoid (B) & 1 & 0.1 \\
\hline Colic (A) & 12 & 1.23 & Kidneys (M) & 24 & 2.46 & Ulcers (A) & 6 & 0.62 \\
\hline Colic of the stomach (A) & 2 & 0.21 & Laxative $(\mathrm{A})$ & 2 & 0.21 & Urinary Infections (M) & 2 & 0.21 \\
\hline Concussions (I) & 2 & 0.21 & Liver (D) & 30 & 3.01 & Urinary Problems (M) & 7 & 0.72 \\
\hline Congestion (A) & 1 & 0.1 & Luck (R) & 15 & 1.54 & Uterus (L) & 3 & 0.31 \\
\hline Contraceptive (L) & 4 & 0.41 & Lungs $(\mathrm{O})$ & 1 & 0.1 & Uterus (cancer) (H) & 2 & 0.21 \\
\hline Cough (O) & 22 & 2.26 & Mal Aire (R) & 12 & 1.23 & Vaginal cleansing (L) & 4 & 0.41 \\
\hline Cysts (L) & 5 & 0.51 & Malaria (E) & 2 & 0.21 & Vaginal discharge (L) & 2 & 0.21 \\
\hline Daño (R) & 20 & 2.05 & Menstrual regulation $(\mathrm{L})$ & 13 & 1.33 & Vomiting (G) & 1 & 0.1 \\
\hline Depression (R) & 10 & 1.03 & Nerves (R) & 49 & 5.03 & Wounds (B) & 20 & 2.05 \\
\hline Detoxification (R) & 1 & 0.1 & Nervousness (R) & 2 & 0.21 & Yellow Fever (Q) & 3 & 0.31 \\
\hline $\begin{array}{l}\text { Detoxification of alcohol } \\
\text { drugs (R) }\end{array}$ & 1 & 0.1 & $\begin{array}{l}\text { Nostalgic Anxiety/Emotional } \\
\text { Trauma (R) }\end{array}$ & 2 & 0.21 & & & \\
\hline Diabetes (F) & 11 & 1.12 & Ovaries (L) & 2 & 0.21 & & & \\
\hline Diarrhea (G) & 9 & 0.92 & Pain (I) & 2 & 0.21 & & & \\
\hline Dizziness (R) & 1 & 0.1 & Pain of Love (R) & 6 & 0.62 & & & \\
\hline Domination (R) & 1 & 0.1 & Parasites (G) & 2 & 0.21 & & & \\
\hline
\end{tabular}

Table 2: Number of mixtures per disease category (letter in parenthesis refers to individual category in table 1)

\begin{tabular}{|c|c|c|}
\hline Application & Number of mixtures used & $\%$ \\
\hline Colic/Intestinal problems (A) & 66 & 6.68 \\
\hline Wounds/external infections (B) & 38 & 3.90 \\
\hline Prostate and other male issues (C) & 30 & 3.08 \\
\hline Gall and Liver ailments (D) & 64 & 6.57 \\
\hline Malaria and Fever (E) & 14 & 1.44 \\
\hline Diabetes $(F)$ & 11 & 1.13 \\
\hline Diarrhea (including parasites) (G) & 16 & 1.64 \\
\hline Cancer $(\mathrm{H})$ & 14 & 1.44 \\
\hline Pain relief (I) & 32 & 3.29 \\
\hline $\begin{array}{l}\text { Arthritis, Rheumatism, Asthma, auto- } \\
\text { immune }(J)\end{array}$ & 43 & 4.41 \\
\hline Heart (K) & 71 & 7.29 \\
\hline Female issues $(\mathrm{L})$ & 64 & 6.57 \\
\hline Kidney and urinary tract $(M)$ & 76 & 7.80 \\
\hline Imflammation (N) & 41 & 4.21 \\
\hline Respiratory tract $(\mathrm{O})$ & 100 & 10.27 \\
\hline Bones $(\mathrm{P})$ & 4 & 0.42 \\
\hline $\begin{array}{l}\text { Viral infections (HIV, Dengue, Yellow Fever } \\
\text { etc.) (Q) }\end{array}$ & 8 & 0.81 \\
\hline Psychosomatic problems (R) & 263 & 27.00 \\
\hline Skin problems & 18 & 1.85 \\
\hline
\end{tabular}




\section{Table 3: Number of mixtures per application}

\begin{tabular}{|c|c|c|}
\hline \# of mixtures & \# of applications & $\%$ \\
\hline 1 & 56 & 34.15 \\
\hline 2 & 36 & 21.95 \\
\hline 3 & 8 & 4.88 \\
\hline 4 & 12 & 7.31 \\
\hline 5 & 4 & 2.44 \\
\hline 6 & 7 & 4.23 \\
\hline 7 & 3 & 1.83 \\
\hline 8 & 4 & 2.44 \\
\hline 9 & 3 & 1.83 \\
\hline 10 & 2 & 1.22 \\
\hline 11 & 3 & 2.44 \\
\hline 12 & 3 & 1.83 \\
\hline 13 & 2 & 1.22 \\
\hline 14 & 0 & 0 \\
\hline 15 & 2 & 1.22 \\
\hline 16 & 3 & 1.83 \\
\hline 17 & 0 & 0 \\
\hline 18 & 1 & 0.61 \\
\hline 19 & 0 & 0 \\
\hline 20 & 2 & 1.22 \\
\hline 21 & 0 & 0 \\
\hline 22 & 2 & 1.22 \\
\hline 23 & 2 & 1.22 \\
\hline 24 & 1 & 0.61 \\
\hline 25 & 1 & 0.61 \\
\hline 26 & 0 & 0 \\
\hline 27 & 0 & 0 \\
\hline 28 & 0 & 0 \\
\hline 29 & 1 & 0.61 \\
\hline 30 & 1 & 0.61 \\
\hline 31 & 0 & 0 \\
\hline 32 & 0 & 0 \\
\hline 33 & 0 & 0 \\
\hline 34 & 0 & 0 \\
\hline 35 & 0 & 0 \\
\hline 36 & 0 & 0 \\
\hline 37 & 0 & 0 \\
\hline 38 & 0 & 0 \\
\hline 39 & 0 & 0 \\
\hline 40 & 0 & 0 \\
\hline 41 & 2 & 1.22 \\
\hline 42 & 0 & 0 \\
\hline 43 & 0 & 0 \\
\hline
\end{tabular}




\begin{tabular}{lll}
\hline 44 & 0 & 0 \\
45 & 0 & 0 \\
46 & 0 & 0 \\
47 & 0 & 0 \\
48 & 0 & 0 \\
49 & 1 & 0.61 \\
50 & 0 & 0 \\
51 & 1 & 0.61 \\
\hline
\end{tabular}

healer seemed to use her/his own specific mixture to treat the problem. This was particularly obvious in the treatment of neurological and psychosomatic problems, for which the majority of plants and mixtures was employed. Up to 49 different preparations were used to treat the same disease. This seems to indicate a high degree of experimentation that is still ongoing in order to find a working cure for unspecific symptoms, and that there is very little consent amongst the individual healers as which cure to employ. This low consensus, especially where spiritual and nervous system/psychosomatic aspects are involved, might also indicate that the individual healers are reluctant to exchange knowledge about their dedicated, specific and guarded treatment methodology in these areas, while the knowledge about "simple" treatments is much more widespread.

Altogether 330 plant species, representing almost $65 \%$ of the medicinal flora used in the region (Bussmann \& Sharon 2006) were applied in mixtures. Of these, 64 species $(19.39 \%)$ were introductions, which falls within the range of introduced species as percentage of the whole medicinally used flora. Amongst the plants employed, Asteraceae expectedly stood out, and the number of species of this family used was comparable to the percentage of Asteraceae in the medicinal flora of the region (Bussmann \& Sharon 2006, Table 4). The overwhelming number of plant mixtures contained 2-7 different plant species, although in the most extreme case 27 distinct species were included (Table 5). A large number of species appeared in various mixtures. For the most important representatives. A complete overview on all plant mixtures used for all illness categories is given in Additional file 1 . The plant species for each mixture are listed in the order given by the curanderos in order to express the importance of the individual species, rather than providing an alphabetical listing. For a detailed overview on quantities and parts of each plant use see [8]. A complete taxonomic overview can be found in Additional file 2 .
The cluster analysis confirmed that mixtures used for applications like inflammations, infections and blood purification, as well as cough, cold, bronchitis or other respiratory disorders, or urinary infection and kidney problems had similar floristic compositions. However, a few interesting clusters stood out: Mixtures used for nervous system disorders, anxiety and heart problems often had a similar composition for example, as did mixtures for prostate and bladder problems; kidney problems, gallbladder disorders, diabetes and cholesterol were treated with the same preparations; as were rheumatic illnesses and asthma. Our research suggests that this indicates that the local healers have a very detailed understanding of disease concepts, and are choosing their remedies very carefully, based on what underlying cause they diagnose, i.e. heart problems get treated differently if they are caused by stress, versus a physical agent, kidney infections are treated differently from kidney problems linked to diabetes and/or obesity. A complete dendrogram is given in Additional file 3, and a complete overview on the number of applications for all species is given in Additional file 4 .

\section{Conclusions}

The floristic composition as well as the complex phytochemistry of traditional herbal mixtures remain woefully understudied. This is the more surprising as traditional one-plant one single-compound based drug discovery efforts have yielded very little results in the last decades, and might in fact be an explanation as to why so many plant species that have been documented for a certain use, are "inefficient" or "toxic" when introduced to clinical trials.

Our research indicates that a large number of plants used in traditional healing in Northern Peru are employed in often sophisticated mixtures, rather than as individual plants. Peruvian curanderos appear to employ very specific guidelines in the preparation of these cocktails, and seem to have a clear understanding of disease 
Table 4: Number of species per family

\begin{tabular}{|c|c|c|c|c|c|}
\hline Family & \# of species & $\%$ & Family & \# of species & $\%$ \\
\hline Asteraceae & 48 & 14.16 & Aizoaceae & 1 & 0.295 \\
\hline Lamiaceae & 22 & 6.49 & Amaryllidaceae & 1 & 0.295 \\
\hline Fabaceae & 17 & 5.01 & Annonaceae & 1 & 0.295 \\
\hline Solanaceae & 15 & 4.44 & Aquifoliaceae & 1 & 0.295 \\
\hline Piperaceae & 10 & 2.95 & Araliaceae & 1 & 0.295 \\
\hline Apiaceae & 9 & 2.65 & Arecaceae & 1 & 0.295 \\
\hline Rosaceae & 8 & 2.36 & Aristolochiaceae & 1 & 0.295 \\
\hline Euphorbiaceae & 8 & 2.36 & Asclepiadaceae & 1 & 0.295 \\
\hline Amaranthaceae & 6 & 1.77 & Balanophoraceae & 1 & 0.295 \\
\hline Lycopodiaceae & 6 & 1.77 & Berberidaceae & 1 & 0.295 \\
\hline Poaceae & 6 & 1.77 & Bixaceae & 1 & 0.295 \\
\hline Rutaceae & 6 & 1.77 & Burseraceae & 1 & 0.295 \\
\hline Orchidaceae & 5 & 1.47 & Capparidaceae & 1 & 0.295 \\
\hline Plantaginaceae & 5 & 1.47 & Chenopodiaceae & 1 & 0.295 \\
\hline Verbenaceae & 5 & 1.17 & Chloranthaceae & 1 & 0.295 \\
\hline Anacardiaceae & 4 & 1.18 & Chrysobalanaceae & 1 & 0.295 \\
\hline Boraginaceae & 4 & 1.18 & Clethraceae & 1 & 0.295 \\
\hline Bromeliaceae & 4 & 1.18 & Crassulaceae & 1 & 0.295 \\
\hline Cucurbitaceae & 4 & 1.18 & Dipsacaceae & 1 & 0.295 \\
\hline Ericaceae & 4 & 1.18 & Elaeocarpaceae & 1 & 0.295 \\
\hline Gentianaceae & 4 & 1.18 & Ephedraceae & 1 & 0.295 \\
\hline Geraniaceae & 4 & 1.18 & Erythroxylaceae & 1 & 0.295 \\
\hline Lauraceae & 4 & 1.18 & Grossulariaceae & 1 & 0.295 \\
\hline Myrtaceae & 4 & 1.18 & Illiciaceae & 1 & 0.295 \\
\hline Polypodiaceae & 4 & 1.18 & Isoetaceae & 1 & 0.295 \\
\hline Valerianaceae & 4 & 1.18 & Juglandaceae & 1 & 0.295 \\
\hline Apocynaceae & 3 & 0.85 & Lythraceae & 1 & 0.295 \\
\hline Caryophyllaceae & 3 & 0.85 & Malesherbiaceae & 1 & 0.295 \\
\hline Convolvulaceae & 3 & 0.85 & Melastomataceae & 1 & 0.295 \\
\hline Lobeliaceae & 3 & 0.85 & Meliaceae & 1 & 0.295 \\
\hline Malvaceae & 3 & 0.85 & Moraceae & 1 & 0.295 \\
\hline Onagraceae & 3 & 0.85 & Myricaceae & 1 & 0.295 \\
\hline Portulacaceae & 3 & 0.85 & Myristicaceae & 1 & 0.295 \\
\hline Rubiaceae & 3 & 0.85 & Oxalidaceae & 1 & 0.295 \\
\hline Urticaceae & 3 & 0.85 & Papaveraceae & 1 & 0.295 \\
\hline Cyperaceae & 3 & 0.85 & Phytolaccaceae & 1 & 0.295 \\
\hline Brassicaceae & 2 & 0.59 & Polygalaceae & 1 & 0.295 \\
\hline Bignoniaceae & 2 & 0.59 & Polygonaceae & 1 & 0.295 \\
\hline Caprifoliaceae & 2 & 0.59 & Proteaceae & 1 & 0.295 \\
\hline Clusiaceae & 2 & 0.59 & Punicaceae & 1 & 0.295 \\
\hline Dioscoreaceae & 2 & 0.59 & Ranunculaceae & 1 & 0.295 \\
\hline Equisetaceae & 2 & 0.59 & Santalaceae & 1 & 0.295 \\
\hline Liliaceae & 2 & 0.59 & Smilacaceae & 1 & 0.295 \\
\hline
\end{tabular}




\section{Table 4: Number of species per family (Continued)}

\begin{tabular}{llllll}
\hline Linaceae & 2 & 0.59 & Thelypteridaceae & 1 & 0.295 \\
Loganiaceae & 2 & 0.59 & Thymeleaceae & 1 & 0.295 \\
Loranthaceae & 2 & 0.59 & Tiliaceae & 1 & 0.295 \\
Monimiaceae & 2 & 0.59 & Tropaeolaceae & 1 & 0.295 \\
Nyctaginaceae & 2 & 0.59 & Typhaceae & 1 & 0.295 \\
Olacaceae & 2 & 0.59 & Ulmaceae & 1 & 0.295 \\
Passifloraceae & 2 & 0.59 & Violaceae & 1 & 0.295 \\
Polemoniaceae & 2 & 0.59 & Xyridaceae & 1 & 0.295 \\
Salicaceae & 2 & 0.59 & Zingiberaceae & 1 & 0.295 \\
Scrophulariaceae & 2 & 0.59 & Zygophyllaceae & & 0.295 \\
Acanthaceae & 1 & 0.295 & & & \\
Adiantaceae & 1 & 0.295 & & & \\
\hline
\end{tabular}

Table 5: Number of mixtures w/number of plants

\begin{tabular}{|c|c|c|}
\hline \# plants per mixture & \# of mixtures & $\%$ \\
\hline 2 & 81 & 8.38 \\
\hline 3 & 113 & 11.69 \\
\hline 4 & 153 & 15.82 \\
\hline 5 & 118 & 12.20 \\
\hline 6 & 126 & 13.03 \\
\hline 7 & 99 & 10.24 \\
\hline 8 & 77 & 7.96 \\
\hline 9 & 68 & 7.03 \\
\hline 10 & 25 & 2.28 \\
\hline 11 & 24 & 2.48 \\
\hline 12 & 17 & 1.76 \\
\hline 13 & 7 & 0.72 \\
\hline 14 & 15 & 1.55 \\
\hline 15 & 2 & 0.21 \\
\hline 16 & 23 & 2.31 \\
\hline 17 & 2 & 0.21 \\
\hline 18 & 2 & 0.21 \\
\hline 19 & 1 & 0.1 \\
\hline 20 & 3 & 0.31 \\
\hline 21 & 7 & 0.72 \\
\hline 22 & 2 & 0.21 \\
\hline 23 & 1 & 0.1 \\
\hline 24 & 0 & 0 \\
\hline 25 & 0 & 0 \\
\hline 26 & 0 & 0 \\
\hline 27 & 1 & 0.1 \\
\hline
\end{tabular}


concepts when they diagnose a patient, which in turn leads them to often apply specific mixtures for specific conditions. There seems to be a widespread exchange of knowledge about mixtures for treatment of bodily diseases, while mixtures for spiritual, nervous system and psychosomatic disorders appear to be more closely guarded by the individual healers.

Traditional herbal mixtures, with their wealth of compound fragments and new compounds originating in the preparation process, could well yield new clues to the treatment of a wide variety of disease. The present paper provides detailed baseline information on composition and use of traditional mixtures in Northern Peru, and further studies to compare the compound composition of these preparations versus single plant extracts, as well as investigations comparing efficacy and toxicity of herbal preparations versus their single plant ingredients are in progress.

\section{Additional material}

Additional file 1 Disease categories and mixtures used for treatment. Additional file $\mathbf{2}$ Scientific plant names and collection numbers. Additional file 3 Dendrograms.

Additional file 4 Most important plant species.

\section{Competing interests}

The authors declare that they have no competing interests.

\section{Authors' contributions}

RB collected/identified plant material under the voucher acronyms "RBU/PL," "ISA," "GER," "JULS," "EHCHL," "VFCHL," "TRUBH", and "TRUVANERICA, and conducted the statistical analysis of the data as well as writing the manuscript. AG conducted laboratory work, data analysis and manuscript composition. AK, KM and AT collected and identified the plant material under "ACR," "KMM," and "ACT," and revised the plant nomenclature of the manuscript. All authors have read and approved the final manuscript.

\section{Acknowledgements}

The presented study was financed through MIRT (Minority International Research and Training) or MHIRT (Minority Health Disparity International Research and Training) as it was recently renamed, a grant from the National Institutes of Health (Fund: 54112B MHIRT Program, Grant: G0000613), initially administered by the Fogarty International Center for Advanced Studies in Washington, D.C. MHIRT-Peru is coordinated by San Diego State University (SDSU) in cooperation with the San Diego Museum of Man (SDMM), the P.A. Hearst Museum of Anthropology at the University of California Berkeley (PAHMA-UCB), and the University of Hawaii at Manoa in the US, and the Universidad Privada Antenor Orrego (UPAO, Herbarium HAO), the Universidad Nacional de Trujillo (UNT, Herbarium HUT and Instituto de Medicina Tropical) and the Clínica Anticona Trujillo (CAT) in Peru. Fieldwork for this project was supported through the assistance of MIRT/MHIRT students Maria Brodine, Gabriel Chait, Christina Dennis, Vanessa Feregrino, Erika Hernández, and Doug Highfill (San Diego State University); Guadalupe Ochoa (San Francisco State University); Cindy Ko (Cal Tech); Yasmin Barocio, Rosalie Cardenas, Mayra Castro, Ricardo González, Gletys Montoya, and Tamia Souto (University of Hawaii at Manoa); Guy Banner (Utah State University); Taisha Ford, Ana Jones, Alexis Lopez, Jennifer Ly, Ryan Martinez, Tahirah Rasheed, Jaime Sarria, Roberto Silva and Melinda Soriano (University of California, Berkeley).

None of the work would have been possible without the invaluable collaboration of our Peruvian colleagues, curanderas Julia Calderón, Isabel Chinguel, and Olinda Pintado, curandero Germán Santisteban, and herbalists Manuel Bejarano, Elmer Cruz, and Iván Cruz. With regard to ritual and therapeutic practices we especially want to thank the above curanderas, as well as curandero Leoncio Carrión.

For three field seasons we were fortunate to have the anthropological expertise of our SDSU colleague Alan Kilpatrick. Project consultants included microbiologists Marisella Aguilera and Doris Diaz; ethnobotanists Pablo Lozano, Jay Chicoin, Carlos Reyes, Jason Schoneman, and Genevieve Gilbreath; biologist Carolina Tellez, and IT specialists John Effio and Steven Skoczen. A special debt of gratitude goes to our dedicated volunteers, Kaye Sharon, Tucker Sharon, and Renee Summerfield.

Thanks also go to Eric Rodriguez (Herbarium Truxillense, HUT) and Abundio Sagastegui, Segundo Leiva, and Mario Zapata (Herbario Antenor Orrego, HAO) for the use of their facilities and assistance in plant identification.

The partial support by the Deutsche Forschungsgemeinschaft (DFG) is acknowledged.

Most of all, we want to express our sincere gratitude to the people of Northern Peru for sharing their ethnobotanical knowledge.

\section{Author Details}

William L Brown Center, Missouri Botanical Garden, PO Box 299, St Louis, MO 63166-0299, USA

Received: 15 January 2010 Accepted: 14 March 2010

Published: 14 March 2010

\section{References}

1. World Health Organization: Consultation Meeting on Traditional Medicine and Modern Medicine, Harmonizing the Two Approaches. Geneva, World Health Organization, (document reference (WP)TM/ICP/TM/001/RB/98-RS/ 99/GE/32(CHN)) 1999.

2. World Health Organization: Traditional, Complementary and Alternative Medicines and Therapies Washington DC, WHO Regional Office for the Americas/Pan American Health Organization (Working group OPS/OMS); 1999.

3. World Health Organization: WHO Traditional Medicine Strategy 2002-2005 World Health Organization, Geneva; 2002.

4. World Health Organization: Report, Technical Briefing on Traditional Medicine. Forty-ninth Regional Committee Meeting, Manila, Philippines, 18 September 1998 Manila, WHO Regional Office for the Western Pacific; 1998.

5. United Nations Conference on Trade and Development: Systems and National Experiences for Protecting Traditional Knowledge, Innovations and Practices Background Note by the UNCTAD Secretariat. Geneva, United Nations Conference on Trade and Development, (document reference TD/B/COM.1/EM.13/2); 2000.

6. Breevort P: The Booming U. S. Botanical Market, A New Overview. HerbalGram 1998, 44:33-46.

7. Camino L: Cerros, plantas y lagunas poderosas, la medicina al norte de Perú 1992.

8. Bussmann RW, Sharon D: Traditional plant use in Northern Peru, Tracking two thousand years of health culture. Journal of Ethnobiology and Ethnomedicine 2006, 2:47.

9. Bussmann RW: Manteniendo el balance de naturaleza y hombre, La diversidad florística andina y su importancia por la diversidad cultural ejemplos del Norte de Perú y Sur de Ecuador. Arnaldoa 2006, 13(2):382-397.

10. De Feo V: Medicinal and magical plants on northern Peruvian Andes. Fitoterapia 1992, 63:417-440.

11. Joralemon D, Sharon D: Sorcery and Shamanism, Curanderos and Clients in Northern Peru University of Utah Press, Salt Lake City; 1993.

12. Polia M: Las Lagunas de los Encantos-Medicina Tradicional Andina en el Peru septentrional Lima, CePeSer; 1988.

13. Sharon D: Wizard of the Four Winds, A Shaman's Story Free Press, New York; 1978.

14. Sharon D: El Chamán de los Cuatro Vientos Siglo veintiuno editores, México, D.F; 1980.

15. Sharon D: Tuno y sus colegas, notas comparativas. In En el Nombre del Señor, Shamanes, demonios y curanderos del norte del Perú Edited by: Millones L, Lemlij M. Australis S.A., Lima; 1994:128-147.

16. Sharon D: Shamanismo y el Cacto Sagrado-Shamanism and the Sacred Cactus San Diego Museum Papers; 2000:37.

17. EsSalud/Organización Panamericana de Salud: Estudio Costo-Efectividad: Programa Nacional de Medicina Complementaria Seguro Social de EsSalud 
(Study of Cost- Effectiveness: National Program in Complementary Medicine. Social Security of EsSalud). Lima, EsSalud/Organización

Panamericana de Salud (Pan American Health Organization); 2000.

18. Cano $\mathrm{JH}$, Volpato $\mathrm{G}$ : Herbal mixtures in the traditional medicine of

Eastern Cuba. Journal of Ethnopharmacology 2004, 90:293-316.

19. Carmona MD, Llorach R, Obon C, Rivera D: "Zahraa", a Unami multicomponent herbal tea widely consumed in Syria: Components of drug mixtures and allegad medicinal properties. Journal of Ethnopharmacology 2005, 102:344-350.

20. Vandebroek I, Balick MJ, Ososki A, Kronenberg F, Yukes J, Wade C, Jiménez F, Peguero B, Castilloin D: The importance of botellas and other plant mixtures in Dominican traditional medicine. Journal of Ethnopharmacology 2010, 128:20-41.

21. Brako L, Zarucchi JL, Eds: Catalogue of the Flowering Plants and Gymnosperms of Peru Missouri Botanical Garden, Saint Louis, MO; 1993.

22. Jørgensen PM, León-Yanez S, Eds: Catalogue of the vascular plants of Ecuador Monographs in Systematic Botany from the Missouri Botanical Garden; 1999:75.

23. McBride JF, Ed: Flora of Peru Fieldiana, Botany. Field Museum of Natural History, Chicago:1936-1981.

24. Jørgensen PM, Ulloa Ulloa C: Seed plants of the High Andes of Ecuador a Checklist. AAU Reports 1994, 34:1-443.

25. Pestalozzi HU: Flora ilustrada altoandina Herbario Nacional de Bolivia and Herbario Forestal Nacional Martín Cardenas, Cochabamba; 1998.

26. Ulloa Ulloa C, Jørgensen PM: Arboles y arbustos de los Andes del Ecuador. AAU Reports 1993, 30:1-263.

27. Sparre G, Harling B: Flora of Ecuador (various authors) Council for Nordic Publications in Botany:1978-2009.

doi: $10.1186 / 1746-4269-6-10$

Cite this article as: Bussmann et al., Herbal mixtures in traditional medicine in Northern Peru Journal of Ethnobiology and Ethnomedicine 2010, 6:10

Submit your next manuscript to BioMed Centra and take full advantage of:

- Convenient online submission

- Thorough peer review

- No space constraints or color figure charges

- Immediate publication on acceptance

- Inclusion in PubMed, CAS, Scopus and Google Scholar

- Research which is freely available for redistribution

Submit your manuscript at www.biomedcentral.com/submit
Ciomed Central 